\title{
Evaluasi Metode Verifikasi Lokasi dan Pemutakhiran Profil Permukiman Kumuh dalam Penyusunan Rencana Pencegahan dan Peningkatan Kualitas Permukiman Kumuh Perkotaan (RP2KPKP)
}

\author{
Istiqomah Ayuningtyas ${ }^{\mathrm{a}}$, Artiningsih ${ }^{\mathrm{b}}$ \\ ${ }^{a}$ Universitas Diponegoro, Semarang
}

\begin{abstract}
Abstrak : Rencana Pencegahan dan Peningkatan Kualitas Permukiman Kumuh Perkotaan (RP2KPKP) merupakan dokumen rencana penyelenggaraan pembangunan kawasan permukiman perkotaan untuk mewujudkan kota bebas kumuh (100-0-100) tahun 2019. Setiap kabupaten/kota dengan potensi terbentuk kawasan kumuh perkotaan wajib menyusun RP2KPKP. Akurasi penyusunan RP2KPKP menjadi penting terutama dalam penentuan lokasi kumuh. Ketidakakuratan lokasi kumuh berpengaruh pada upaya penanganan dan angka capaian bebas kumuh. Artikel ini fokus pada evaluasi metode verifikasi lokasi dan pemutakhiran profil permukiman kumuh. Evaluasi dilakukan berdasarkan panduan penyusunan RP2KPKP oleh Dirjen Cipta Karya Kementerian PUPR yang dibandingkan dengan metode alternatif guna mempermudah penentuan lokasi kumuh dan meningkatkan akurasi analisis. Hasil evaluasi menunjukkan bahwa banyaknya desa/kelurahan yang diobservasi menjadi celah terjadinya kesalahan pengambilan sampel. Beberapa konsekuensi yang timbul adalah: 1) terkendalanya profil permukiman, sehingga tidak semua desa/kelurahan memiliki baseline 100-0-100,2) tumpang tindihnya metode verifikasi lokasi dan pemutakhiran profil permukiman kumuh dengan metode pada tahap lain, 3) ketidaklengkapan output verifikasi lokasi dan pemutakhiran profil permukiman kumuh akibat keterbatasan biaya dan tantangan jangkauan dari banyaknya desa/kelurahan yang perlu disurvei. Observasi 7 aspek kumuh melalui penginderaan jauh dengan metode ObjectOriented Image Analysis (OOA) dapat menekan jumlah kebutuhan waktu, tenaga, dan biaya.
\end{abstract}

Kata kunci: Rencana Pencegahan dan Peningkatan Kualitas Permukiman Kumuh Perkotaan (RP2KPKP); Kumuh Perkotaan; Bebas Kumuh; Alternatif Metode Verifikasi Lokasi Kumuh; Object-Oriented Image Analysis (OOA)

\section{A. PENDAHULUAN}

Rencana Pencegahan dan

Peningkatan Kualitas Permukiman

Kumuh Perkotaan (RP2KPKP) merupakan dokumen rencana penyelenggaraan pembangunan kawasan permukiman perkotaan yang difokuskan pada pola pencegahan dan peningkatan kualitas permukiman kumuh perkotaan. RP2KPKP digunakan sebagai acuan bagi seluruh stakeholder dalam mengimplementasikan program dan kegiatan yang terpadu dan bersinergi. Dokumen perencanaan ini disusun guna mempercepat penanganan permukiman kumuh perkotaan secara menyeluruh dan tuntas bagi kawasan kumuh perkotaan yang deliniasi dan indikatornya ditetapkan melalui Surat Keputusan (SK) Bupati/Walikota dalam jangka waktu kegiatan selama 5 tahun (sampai tahun 
2019) atau tercapainya kabupaten/kota bebas kumuh (Direktorat Jenderal Cipta Karya, 2016). Penyusunan dokumen RP2KPKP juga merupakan upaya negara dalam melindungi segenap bangsa Indonesia melalui penyelenggaraan perumahan dan kawasan permukiman agar masyarakat mampu bertempat tinggal serta menghuni rumah yang layak dan terjangkau di dalam lingkungan yang sehat, aman, harmonis, dan berkelanjutan di seluruh wilayah Indonesia yang tertuang pada UU No. 1 Tahun 2011 tentang perumahan dan kawasan permukiman. Oleh karenanya, penyusunan dokumen RP2KPKP menjadi penting pada seluruh kabupaten/kota yang memiliki kawasan kumuh perkotaan berdasarkan SK Bupati/Walikota atau yang memiliki potensi terbentuknya kawasan kumuh perkotaan.

Penentuan pelaksana kegiatan penyusunan RP2KPKP melalui lelang kepada konsultan berkualifikasi baik, cenderung dimenangkan oleh konsultan asal ibu kota provinsi atau kota-kota besar lainnya, sedangkan lokasi sasaran belum tentu mudah diakses konsultan pemenang lelang. Hal tersebut potensial sebagai faktor penghambat proses pengumpulan data lokasi sasaran yang menjadi bahan verifikasi lokasi dan pemutakhiran profil permukiman kumuh. P2KPKP Kabupaten Pekalongan dikerjakan oleh PT. Vasa Sarwahita yang berdomisili di Kota Semarang bagian Selatan, tepatnya di Kecamatan Banyumanik. Jarak antara kantor PT. Vasa Sarwahita menuju pusat Kabupaten Pekalongan adalah $130 \mathrm{~km}$ dengan waktu tempuh selama 2 jam 55 menit yang merupakan rute tercepat melalui jalan tol. Sulitnya akses akan berimplikasi pada pembiayaan survei ke lokasi potensial kumuh. Juga bisa menyebabkan pemadatan durasi waktu survei oleh tim pelaksana.

Ketidaklengkapan informasi dalam pengumpulan data di lapangan bisa mempengaruhi hasil penentuan lokasi kumuh dan upaya penanganan yang direkomendasikan pada pencapaian kabupaten/kota bebas kumuh tahun 2019. Oleh karenanya, perlu dilakukan evaluasi metode verifikasi lokasi dan pemutakhiran profil permukiman kumuh dalam penyusunan RP2KPKP beserta 7 aspek dan kriteria masing-masing dalam penentuan perumahan dan permukiman kumuh. Aspek dan kriteria tersebut tertuang pada Peraturan Menteri Pekerjaan Umum dan Perumahan Rakyat No. 02/PRT/M/2016 yang diterjemahkan pada Panduan Penyusunan RP2KPKP oleh Kementerian Pekerjaan Umum dan 
Perumahan Rakyat Direktorat Jendral

Cipta Karya. Kelemahan untuk verifikasi akan coba dipenuhi melalui ObjectOriented Image Analysis (OOA) sebagai alternatif metode. Metode penentuan kawasan kumuh melalui penginderaan jauh dengan metode OOA dalam penggunaannya telah dilakukan penelitian pada penentuan kawasan kumuh di negara-negara Asia, Afrika sub-Sahara, dan Amerika Latin.

\section{B. METODE}

\section{Lingkup Kasus}

Evaluasi dilakukan pada
Kabupaten Pekalongan. Lingkup kasus RP2KPKP Kabupaten Pekalongan meliputi kawasan perkotaan Kabupaten Pekalongan, yaitu 69 desa di 11 kecamatan. Pemilihan lokasi kumuh dan deliniasi kawasan kumuh terhadap lingkup kasus akan menggunakan 7 aspek penilaian beserta kriteria dan petimbangan lain, yang menghasilkan 29 kawasan kumuh. Distribusi kawasan kumuh Kabupaten Pekalongan dapat dilihat pada Gambar 1 (PT. Vasa Sarwahita, 2016).

pelaksanaan penyusunan RP2KPKP

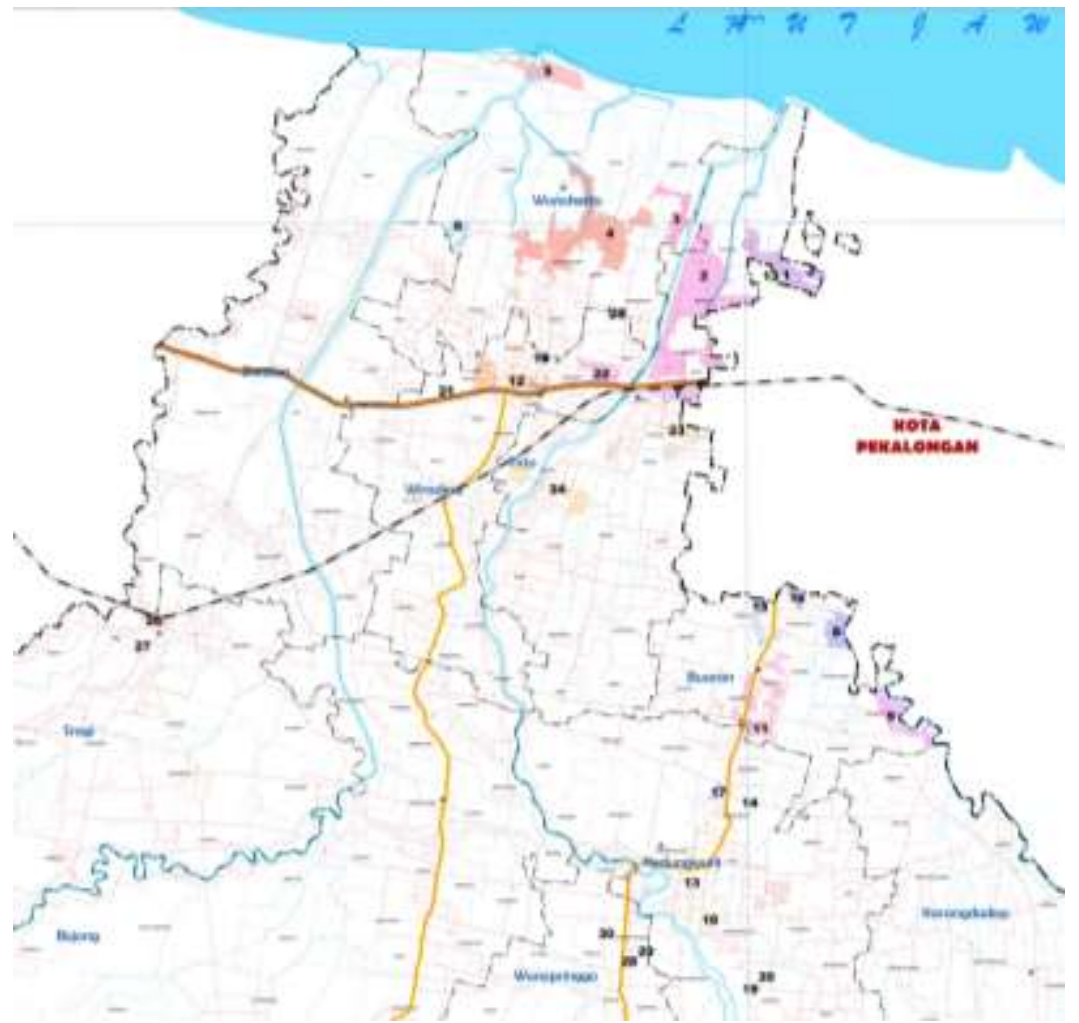

Gambar 1. Distribusi Kawasan Kumuh Kabupaten Pekalongan/ (PT. Vasa Sarwahita, 2016) 


\section{Metode Evaluasi}

Evaluasi dilakukan dengan metode TBA (Theory Based Approach), yaitu metode yang menggunakan teori sebagai acuan. Evaluasi ini dilakukan dengan melakukan penilaian yang menggunakan acuan berupa Panduan Penyusunan RP2KPKP yang dikeluarkan oleh Dirjen Cipta Karya Kementerian PUPR. Hasil dari penilaian ini akan menunjukkan kinerja metode verifikasi lokasi dan pemutakhiran profil permukiman kumuh dalam penyusunan RP2KPKP Kabupaten Pekalongan sebagai gambaran pelaksanaan metode verifikasi lokasi dan pemutakhiran profil permukiman kumuh yang ada pada Panduan Penyusunan RP2KPKP. Tindak lanjut dari temuan ini adalah pencarian metode alternatif pendamping untuk mempermudah penentuan lokasi kumuh dan meningkatkan akurasi analisis.

\section{KAJIAN LITERATUR}

\section{Penyusunan RP2KPKP}

Pemerintah kabupaten/kota perlu menyusun dan memiliki rencana aksi penanganan dan pencegahan permukiman kumuh yang kemudian diperlukan skenario, konsep dan strategi penanganan yang akan diisi oleh substansi RP2KPKP. RP2KPKP menjabarkan kebijakan makro terkait pencegahan perkembangan permukiman kumuh kabupaten/kota serta konsep penanganan kawasan permukiman kumuh prioritas, dalam implementasinya akan menjadi acuan bagi penyusunan strategi sektor dan rencana induk sistem komponenkomponen pembentuk permukiman. Dalam konteks pembangunan permukiman, strategi sektor dan rencana induk sistem yang telah disusun secara sistematis dan sinergi ini nantinya akan menjadi masukan dalam proses penyusunan memorandum program yang selanjutnya akan diterjemahkan kedalam desain teknis (PT. Vasa Sarwahita, 2016).

Berdasarkan Undang-Undang No. 1 Tahun 2011, penyelenggaraan kawasan permukiman perlu didasarkan pada suatu dokumen rencana yang terpadu dan terintegrasi yaitu Rencana Kawasan Permukiman, dapat diartikan pula bahwa dalam konteks penanganan permukiman kumuh perlu juga memiliki suatu instrumen yang dapat menaungi upaya pencegahan dan peningkatan permukiman kumuh yaitu RP2KPKP. RP2KPKP diharapkan dapat menjadi satu-satunya acuan pemerintah daerah dalam upaya pencegahan dan 
peningkatan kualitas permukiman kumuh serta menjadi program yang menyinergikan program-program pencegahan dan peningkatan kualitas permukiman kumuh (program penanganan permukiman kumuh dari Pemerintah Kab./Kota, Neighborhood Upgrading and Shelter Project (NUSP)-
SIAP, P2KKP/KOTAKU, program regular dari APBN/Provinsi, dll). Tahapan penyusunan RP2KPKP terbagi ke dalam 4 tahapan yang dilaksanakan dalam kurun waktu 6 bulan. Penjabaran dari keempat tahapan tersebut dapat dilihat pada Gambar 2 (Direktorat Jenderal Cipta Karya, 2016).

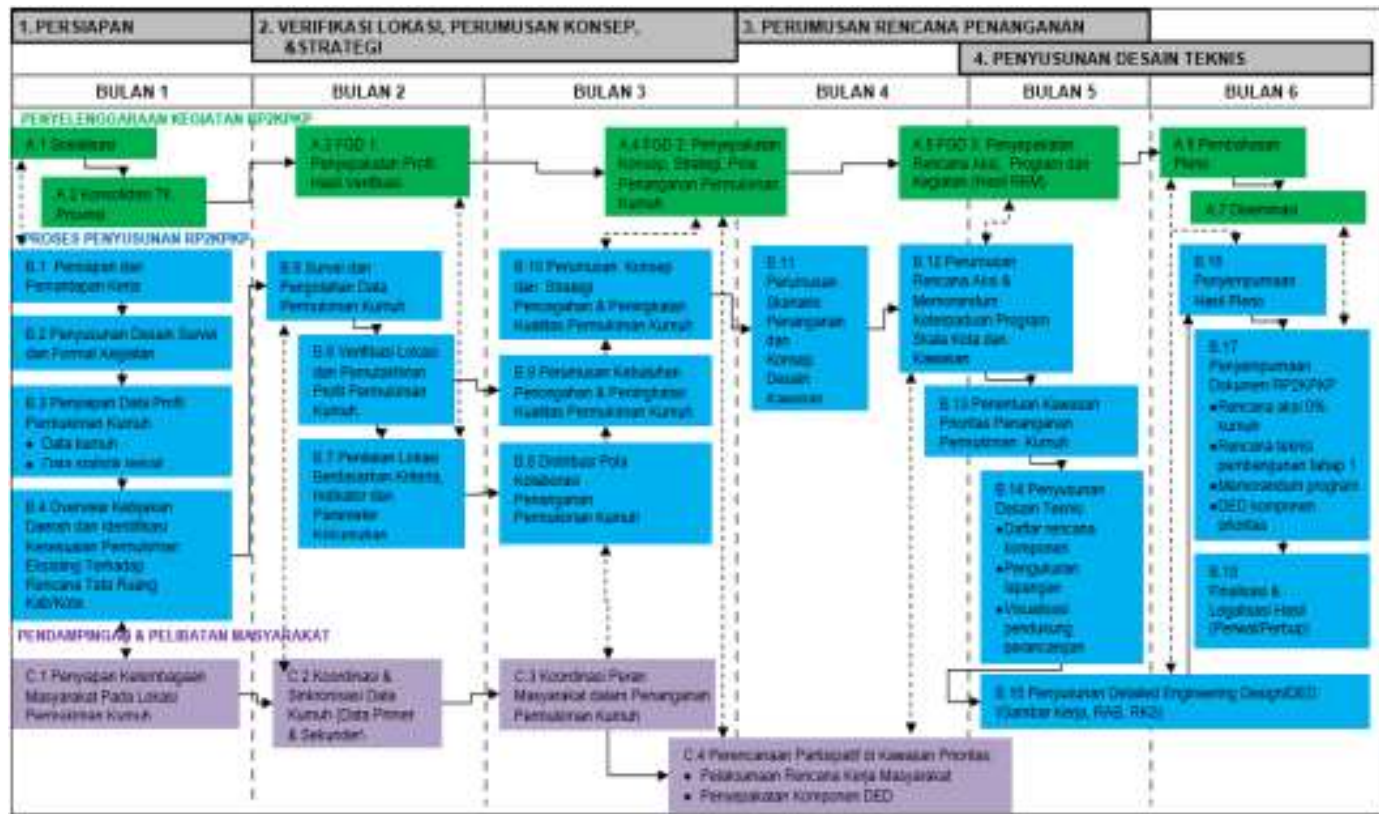

Gambar 2. Tahapan penyusunan RP2KPKP (Direktorat Jenderal Cipta Karya, 2016)

Pelaksanaan verifikasi lokasi dan pemutakhiran profil permukiman kumuh dalam penyusunan RP2KPKP dilaksanakan pada tahap verifikasi lokasi serta perumusan konsep dan strategi yang dilakukan sejak kegiatan persiapan selesai dilakukan. Untuk mencapai verifikasi lokasi dan pemutakhiran profil permukiman kumuh dilakukan terlebih dahulu survei dan pengolahan data permukiman kumuh serta pelibatan masyarakat dalam hal koordinasi dan sinkronisasi data kumuh untuk mendapatkan data yang akurat sebagai bahan pertimbangan penentuan permukiman kumuh. Tahapan yang perlu dilakukan dapat dilihat pada nomor B.5, C.2, dan B.6 di Gambar 2 dengan penjabaran sebagai berikut (Direktorat Jenderal Cipta Karya, 2016):

1. Survei dan pengolahan data permukiman kumuh merupakan 
proses identifikasi untuk memahami kondisi permukiman kumuh berikut sebaran lokasi, konstelasinya terhadap ruang kota/perkotaan, mengidentifikasi tipologi permukiman kumuh, serta potensi dan permasalahan yang terkait dengan karakteristik sosial, ekonomi, budaya, fisik, dan kelembagaan. Identifikasi ini diperlukan sebagai dasar verifikasi lokasi dan pemutakhiran profil permukiman kumuh yang telah ditetapkan di dalam SK Bupati/Walikota. Metode yang digunakan berupa survei dan observasi, konsolidasi dan analisis data, pemetaan isu strategis, potensi, dan permasalahan serta diskusi. Output dari kegiatan ini adalah daftar dan peta sebaran permukiman kumuh skala kota/perkotaan (termasuk permukiman kumuh yang berada diluar SK), matriks isu-isu strategis kawasan perkotaan dan permukiman kumuh perkotaan, karakteristik permukiman kumuh kota/perkotaan yang didalamnya memuat kesimpulan mengenai kondisi fisik, sosial budaya, ekonomi, kelembagaan, dan konstelasi terhadap ruang kota/perkotaan, serta kesesuaian SK dengan profil kumuh hasil survei dan pengolahan data kumuh.
2. Koordinasi dan sinkronisasi data kumuh merupakan kegiatan diskusi dalam rangka mengkonsolidasikan hasil identifikasi terhadap data profil permukiman kumuh yang telah diperoleh dari hasil survei sekunder maupunprimer serta hasil pengolahan data permukiman yang diperoleh dari data baseline maupun data statistik lainnya yang menjadi rujukan data permukiman kumuh. Metode yang digunakan berupa diskusi bersama masyarakat. Output dari kegiatan ini adalah hasil sinkronisasi data permukiman kumuh dan basis data permukiman kumuh sebagai dasar verifikasi lokasi permukiman kumuh.

3. Verifikasi lokasi dan pemutakhiran profil permukiman kumuh merupakan bagian dari proses pemutakhiran profil permukiman kumuh untuk memperoleh data dan informasi permukiman kumuh terkini secara detail, akurat, dan terukur sebagai dasar perumusan konsep dan strategi pencegahan dan peningkatan kualitas permukiman kumuh perkotaan yang sesuai dengan kebutuhan penanganan. Kegiatan ini menggunakan metode observasi lapangan, cek silang dengan hasil identifikasi awal, dan FGD. Output dari kegiatan ini adalah data hasil pemutakhiran SK, daftar permukiman 
kumuh yang telah terverifikasi, datadata terverifikasi lokasi permukiman kumuh yang terdiri dari lokasi, deliniasi, luasan, dan layanan hunian dan infrastruktur (by name by address), pemutakhiran profil detail permukiman kumuh yang mencakup data fisik yang terkait dengan 7 indikator kumuh dan data non-fisik lingkungan permukiman (by name by address), peta sebaran permukiman kumuh hasil verifikasi pada skala 1:25.000-1:10.000, peta deliniasi permukiman kumuh hasil verifikasi pada skala 1:5.000 dalam bentuk peta citra dan peta garis, melakukan dokumentasi visual (foto, video drone) untuk seluruh permukiman kumuh perkotaan, dan berita acara verifikasi lokasi. Secara skematis, kedudukan verifikasi permukiman kumuh, dapat dilihat pada Gambar 3.

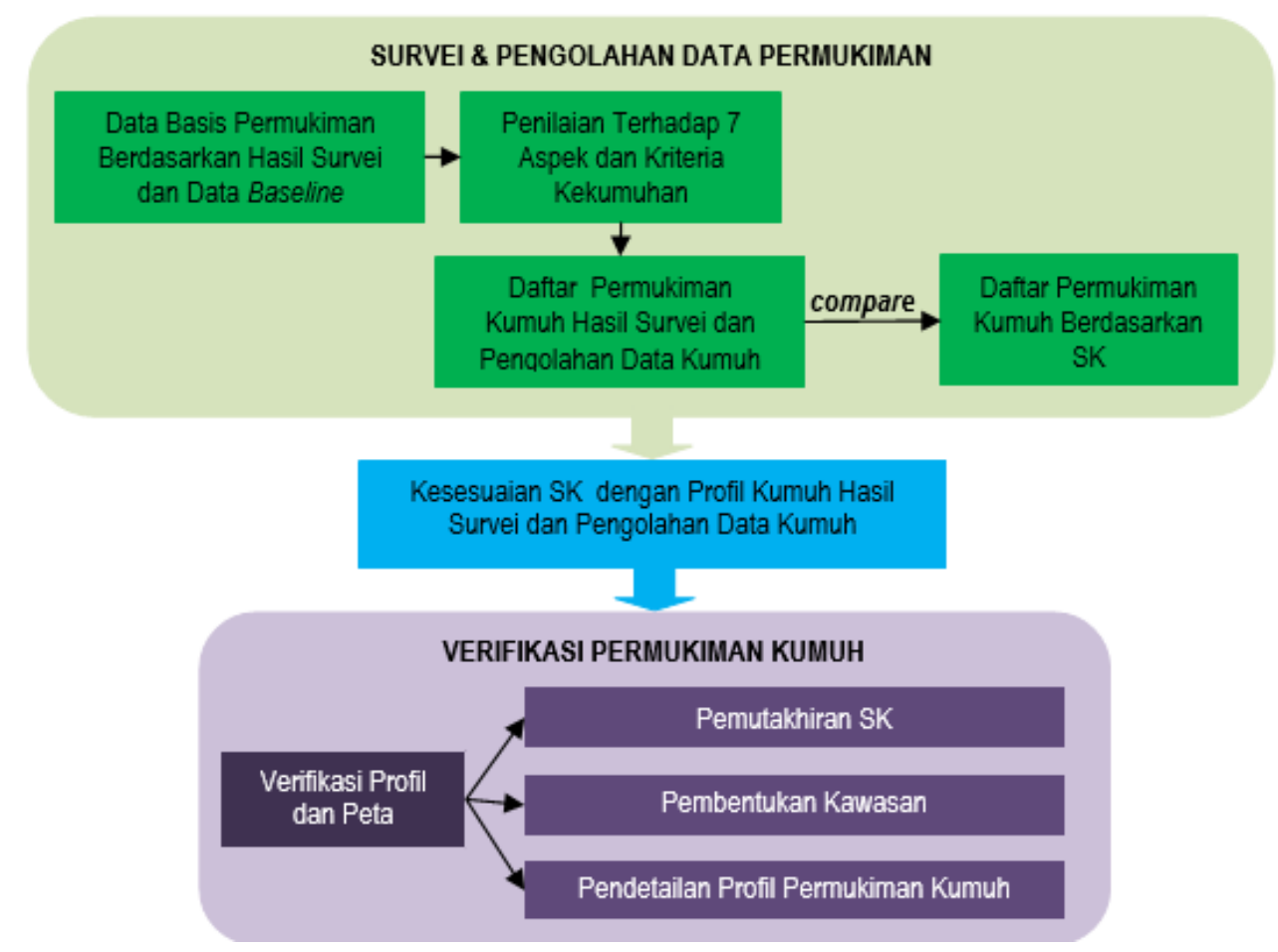

Gambar 3. Kedudukan Verifikasi Lokasi Permukiman Kumuh

Sumber: Direktorat Jenderal Cipta Karya, 2016

2. Metode Object-Oriented Image Analysis (OOA) sebagai Alternatif Verifikasi Lokasi Kumuh

Baru-baru ini dikembangkan metode OOA yang memiliki tujuan untuk meniru usaha mengenali sesuatu melalui pengalaman sendiri oleh manusia dan dimulai dengan segmentasi 
data gambar pada skala spasial yang berbeda dan tergantung pada tingkat generalisasi yang diinginkan, resolusi spasial citra, serta skala yang melekat pada objek. Metode berbasis OOA ini memiliki potensi untuk menangkap heterogenitas dengan mengikuti prosedur hirarkis untuk objek-klasifikasi dan dengan memasukkan informasi kontekstual untuk objek dan fitur nonfisik (Ebert, Kerle, \& Stein, 2009). Metode berbasis OOA menawarkan potensi untuk mengintegrasikan karakteristik spektral, spasial dan kontekstual untuk klasifikasi. OOA dapat digunakan untuk mengklasifikasikan permukiman informal dari sebuah citra Ikonos. Hasil ini kemudian ditingkatkan dengan mengembangkan konteks ontologi khusus untuk mendeteksi permukiman informal menggunakan data Quickbird (Kohli, Warwadekar, Kerle, Sliuzas, \& Stein, 2013). OOA juga membuat penggunaan efektif proxy fisik untuk menandai atribut perkotaan yang tidak langsung diamati, misalnya untuk penilaian kerentanan sosial (Kohli, Stein, \& Sliuzas, 2016).OOA menekankan pada pendapat ahli dalam menafsirkan definisi kumuh dan cara mengukurnya. Penelitian Kohli, Sliuzas, Kerle, \& Stein (2012) dengan menggunakan 50 ahli (perencana kota, para ahli penginderaan jauh, akademisi dan administrator lokal) meliputi 16 negara di Asia, Afrika sub-Sahara, dan Amerika Latin. Dilakukan survei semi terstruktur melalui kuesioner dengan para ahli yang berisikan pertanyaan terbuka mengenai definisi kumuh yang dituangkan menjadi indikator umum, membuat karakteristik kumuh dari setiap indikator umum, serta bagian dari karakteristik kumuh yang dapat dilihat melalui citra dengan resolusi tinggi. Hasil kuesioner dari para ahli dapat diuraikan sebagai berikut (Kohli, Sliuzas, Kerle, \& Stein, 2012):

1. Karakteristik bangunan dapat dinilai dari material atap bangunan (warna), bentuk bangunan, serta orientasi bangunan;

2. Jaringan akses dapat dinilai dari kondisi jalan (beraspal/tidak), lebar jalan, jenis jalan, struktur jalan (teratur/tidak), serta akses jaringan (keterhubungan dengan daerah sekitar);

3. Bentuk permukiman dapat dinilai dari apakah mengikuti bentuk fitur, seperti jalan, rel kereta api, dan saluran drainase, jarak dari fitur tersebut, serta bentuk permukiman yang memanjang/linier dan tidak teratur; 
4. Kepadatan bangunan dapat dinilai dari cakupan atap, kepadatan bangunan (berbeda pada setiap daerah dan sesuai dengan usia permukiman), serta asosiasi dengan daerah sekitarnya;

5. Lokasi permukiman yang berada pada kawasan yang tidak stabil, seperti zona banjir, kelerengan curam, dekat dengan jalur kereta api, jalan raya, atau jalan-jalan utama, dekat Saluran Udara Tegangan Ekstra Tinggi (SUTET), dekat industri berbahaya, terhubung ke infrastruktur di daerah tetangga, dekat/dalam lingkungan status sosial-ekonomi rendah/menengah/tinggi, serta dekat dengan lapangan pekerjaan; dan

6. Karakteristik lingkungan berupa berada pada status sosial-ekonomi rendah, dekat/pada status sosialekonomi menengah/tinggi, dekat/pada area industri/CBD, serta bagian dari kawasan kumuh.

Penelitian Kohli, Stein, \& Sliuzas (2016) menggunakan 50 reponden yang meliputi 3 ahli lingkungan perkotaan yang berbeda. Proses yang dilakukan dengan survei semi terstruktur melalui kuesioner dengan para ahli dengan menanyakan perihal persepsi / definisi / pengalaman kumuh, yang kemudian mendapatkan penentuan kumuh dan karakteristik khusus dari kawasan kumuh. Selain itu responden juga diminta untuk melakukan digitasi pada citra satelit dengan resolusi tinggi pada suatu lokasi yang digunakan untuk identifikasi dan deliniasi disertai dengan alasannya (jika ada). Hasil dari 50 responden hanya 19 digitasi yang dapat digunakan dengan karakteristik responden berupa 10 responden dengan pengetahuan dasar dan 9 responden dengan pengetahuan ahli pada bidang kumuh dan penginderaan jauh. Pada pengklasifikasian kawasan kumuh dipilihlah 5 tingkatan kekumuhan melalui skala Likert dengan 5 poin, dengan poin 1 untuk sangat kumuh dan poin 5 untuk sangat baik. Untuk lokasi yang dipilih oleh lebih dari 15 responden atau $80 \%$ responden dapat diklasifikasikan bahwa lokasi tersebut kemungkinan besar merupakan sebagai kawasan kumuh.

\section{HASIL DAN PEMBAHASAN}

Pembahasan ini akan mencakup evaluasi metode verifikasi lokasi dan pemutakhiran profil permukiman kumuh dalam penyusunan RP2KPKP beserta 7 aspek dan kriterianya yang digunakan dalam penentuan lokasi dan kawasan kumuh. Dilakukan terlebih dahulu pembahasan terkait tahap persiapan yang membahas survei dan pengolahan data permukiman kumuh serta 
koordinasi dan sinkronisasi data kumuh bersama masyarakat yang pada prosesnya dapat mempengaruhi hasil dari verifikasi lokasi dan pemutakhiran profil permukiman kumuh. Pada kajian ini juga akan dilakukan perbandingan metode penentuan kawasan kumuh melalui penginderaan jauh dengan metode OOA yang dalam penggunaannya telah dilakukan penelitian pada penentuan kawasan kumuh di negara-negara Asia, Afrika sub-Sahara, dan Amerika Latin.

\section{Tahap Persiapan}

Pembahasan tahap persiapan akan dibagi menjadi pembahasan survei dan pengolahan data permukiman kumuh yang dalam pelaksanaannya berdampingan dengan pembahasan koordinasi dan sinkronisasi data kumuh bersama masyarakat. Pada survei dan pengolahan data permukiman kumuh menggunakan metode (1) survei dan observasi, (2) konsolidasi dan analisis data, (3) pemetaan isu strategis, potensi, dan permasalahan serta (4) diskusi sesuai dengan Panduan Penyusunan RP2KPKP. Desa/kelurahan yang perlu disurvei dan diobservasi terdiri atas desa/kelurahan yang sudah tercantum pada SK Bupati/Walikota dan desa/kelurahan yang berpotensi kumuh. Hal ini berarti seluruh desa/kelurahan yang berada pada kawasan perkotaan kabupaten/kota dan menjadi berat jika dilakukan pada kabupaten yang memiliki desa/kelurahan yang lebih banyak dibandingkan kota. Jika nilai proyek penyusunan RP2KPKP di kabupaten tidak cukup besar untuk membiayai itu semua, konsultan cenderung menyiasatinya dengan mengambil sampel pada daerah dengan karakteristik yang serupa dan dapat menurunkan tingkat akurasi. Konsolidasi dan analisis data dilakukan dalam bentuk pendeskripsian hasil observasi lapangan. Hal ini mengakibatkan untuk lokasi yang hanya diambil sampelnya tidak dapat memberikan gambaran secara spesifik.

Pemetaan isu strategis, potensi, dan permasalahan dengan tingkat kawasan perkotaan hanya mampu menampilkan gambaran secara umum kondisi dari tiap aspek kumuh. Metode terakhir berupa diskusi merupakan bentuk dari koordinasi dan sinkronisasi data kumuh bersama masyarakat. Di lapangan sering kali tidak terjadi diskusi mandiri yang dilakukan oleh konsultan. Diskusi seringkali hanya dapat terjadi jika telah dikoordinasikan oleh Pemda dalam bentuk FGD. Profil permukiman kumuh dapat diolah dengan menggunakan baseline 100-0-100 yang 
didapatkan dari Badan Keswadayaan Masyarakat (BKM) pada tingkat desa/kelurahan. Namun tidak semua desa/kelurahan memiliki baseline tersebut. Pada Kabupaten Pekalongan, terdapat desa/kelurahan yang tidak memiliki baseline 100-0-100, yaitu pada desa/kelurahan di Kecamatan Doro, Kecamatan Kajen, dan Kecamatan Sragi. Pada desa/kelurahan yang tidak memiliki baseline 100-0-100 perlu dilakukan survei secara menyeluruh untuk mendapatkan basis data permukiman kumuh.

\section{Tahap Verifikasi Lokasi dan Pemutakhiran Profil Permukiman Kumuh}

Tahap ini dilakukan dengan menggunakan metode (1) observasi lapangan, (2) cek silang dengan hasil identifikasi awal, dan (3) FGD. Pada tahap ini konsultan cenderung tidak melakukan observasi lapangan karena telah dilakukan pada pada survei dan pengolahan data permukiman kumuh. Cek silang dengan hasil identifikasi awal dilakukan melalui megggabungan referensi yang didapatkan dari hasil overview kebijakan daerah dan identifikasi kesesuaian permukiman eksisting terhadap rencana tata ruang kabupaten serta basis data permukiman kumuh yang telah disusun pada tahap persiapan. FGD yang dilakukan merupakan bagian dari FGD yang juga diperlukan untuk tahap penilaian lokasi berdasarkan kriteria, indikator dan parameter kekumuhan serta tahap distribusi pola kolaborasi penanganan permukiman kumuh. FGD dengan bahasan profil permukiman kumuh pada Penyusunan RP2KPKP Kabupaten Pekalongan diselenggarakan pada 19 Mei 2016.

Output dari tahap ini sesuai dengan Panduan Penyusunan RP2KPKP adalah data hasil pemutakhiran SK, daftar permukiman kumuh yang telah terverifikasi, data-data terverifikasi lokasi permukiman kumuh yang terdiri dari lokasi, deliniasi, luasan, dan layanan hunian dan infrastruktur (by name by address), pemutakhiran profil detail permukiman kumuh yang mencakup data fisik yang terkait dengan 7 indikator kumuh dan data non-fisik lingkungan permukiman (by name by address), peta sebaran permukiman kumuh hasil verifikasi pada skala 1:25.000-1:10.000, peta deliniasi permukiman kumuh hasil verifikasi pada skala 1:5.000 dalam bentuk peta citra dan peta garis, melakukan dokumentasi visual (foto, video drone) untuk seluruh permukiman kumuh perkotaan, dan berita acara verifikasi lokasi. Namun jika nilai proyek penyusunan RP2KPKP 
di kabupaten tidak cukup besar untuk membiayai itu semua, maka tidak ada output data verifikasi lokasi permukiman kumuh berupa layanan hunian dan infrastruktur (by name by address), pemutakhiran profil detail permukiman kumuh berupa data nonfisik lingkungan permukiman (by name by address), dan dokumentasi visual berupa video drone untuk seluruh permukiman kumuh perkotaan, seperti pada RP2KPKP Kabupaten Pekalongan.

\section{Perbandingan dengan Metode OOA}

Pada penentuan kawasan kumuh dalam penyusunan RP2KPKP dilakukan melalui identifikasi dalam 3 tahap, yaitu tahap identifikasi kondisi kumuh dengan aspek kondisi bangunan, kondisi jalan lingkungan, kondisi penyediaan air minum, kondisi drainase lingkungan, kondisi pengelolaan air limbah, pengelolaan sampah, dan kondisi proteksi kebakaran serta ditambahkan kondisi ruang terbuka hijau (RTH); identifikasi legalitas lahan dengan aspek legalitas lahan; serta identifikasi pertimbangan lain dengan kriteria nilai strategis lokasi, kependudukan, kondisi sosial, ekonomi, dan budaya. Data yang digunakan untuk identifikasi merupakan data yang diperoleh pada kegiatan survei dan pengolahan data permukiman kumuh yang dirasa kurang kuat dalam pengumpulan data kondisi eksisting dikarenakan faktor jangkauan dan banyaknya desa/kelurahan pada kawasan perkotaan. Hal ini dapat mempengaruhi akurasi lokasi kumuh, upaya penanganan, dan berdampak pada pencapaian bebas kumuh.

Pada upaya penentuan kawasan kumuh terdapat banyak metode yang dapat digunakan, salah satunya adalah metode penentuan kawasan kumuh melalui penginderaan jauh dengan metode OOA yang dalam penggunaannya telah dilakukan penelitian pada penentuan kawasan kumuh di negara-negara Asia, Afrika sub-Sahara, dan Amerika Latin. Metode ini umumnya dilakukan dengan cara melakukan penyebaran kuesioner terbuka kepada ahli di bidang perencana kota, penginderaan jauh, akademisi, dan administrator lokal. Kuesioner ini dilakukan guna memperoleh persepsi/definisi/pengalaman kumuh para ahli untuk disusun menjadi definisi kumuh yang dituangkan menjadi indikator kumuh serta karakteristik kumuh yang dapat dilihat melalui citra dari setiap indikator kumuh. Penggunaan metode ini dapat menghasilkan indikator beserta karakteristiknya yang berbeda pada setiap daerah sehingga tidak dapat 
digeneralisasi tetapi dapat digunakan untuk melihat kesamaan karakteristik dari daerah kumuh. Selain itu, metode ini tidak mengharuskan adanya kegiatan observasi lapangan secara menyeluruh, sehingga dapat mengurangi kebutuhan waktu, tenaga, dan biaya karena indikator yang digunakan telah mengarah pada karakteristik yang dapat dianalisis melalui penginderaan jauh dengan citra dengan resolusi tinggi ataupun Google Earth yang dapat diakses tanpa mengeluarkan biaya.

\section{E. KESIMPULAN}

Kesimpulan yang didapatkan adalah:

1. Konsultan menekan biaya observasi dan pengolahan data permukiman terutama pada kabupaten dengan banyak desa/kelurahan yang dikategorikan sebagai kawasan perkotaan. Pengambilan sampel pada tahap observasi tidak memberikan gambaran lengkap pada lokasi bukan sampel.

2. Kelemahan profil permukiman kumuh akibat tidak semua desa/kelurahan memiliki BKM yang menyusun baseline 100-0-100.

3. Tumpang tindih proses antar tahap menyebabkan metode verifikasi lokasi dan pemutakhiran profil permukiman kumuh tidak dapat berdiri sendiri dalam pelaksanaannya atau sebenarnya tidak perlu metode tertentu karena sudah ada pada tahap yang lain.

4. Ketidaklengkapan output verifikasi lokasi dan pemutakhiran profil permukiman kumuh dikarenakan keterbatasan biaya untuk menyusun data yang perlu disajikan dalam bentuk by name by address dan dokumentasi visual berupa video drone untuk seluruh permukiman kumuh perkotaan.

5. Pencapaian bebas kumuh dipengaruhi oleh akurasi lokasi kumuh dengan tantangan jangkauan dan banyaknya desa/kelurahan yang perlu diobservasi pada kawasan perkotaan.

\section{Ucapan Terima Kasih}

Terima kasih kepada PT. Vasa Sarwahita yang telah memberikan kesempatan untuk dapat berpartisipasi dalam penyusunan dan berbagi dokumen RP2KPKP Kabupaten Pekalongan sebagai gambaran dalam penyusunan artikel ini.

\section{F. DAFTAR PUSTAKA}

Direktorat Jenderal Cipta Karya. (2016). Panduan Penyusunan RP2KPKP. Jakarta: Kementerian Pekerjaan Umum dan Perumahan Rakyat. 
Ebert, A., Kerle, N., \& Stein, A. (2009). Urban social vulnerability assessment with physical proxies and spatial metrics derived from air- and spaceborne imagery and GIS data. Natural Hazards , 275-294.

Kohli, D., Sliuzas, R., Kerle, N., \& Stein, A. (2012). An ontology of slums for image-based classification. Computers, Environment and Urban Systems , 154-163.

Kohli, D., Stein, A., \& Sliuzas, R. (2016). Uncertainty analysis for image interpretations of urban slums. Computers, Environment and Urban Systems , 37-49.
Kohli, D., Warwadekar, P., Kerle, N., Sliuzas, R., \& Stein, A. (2013). Transferability of Object-Oriented Image Analysis Methods for Slum Identification. Remote Sensing, 4209-4228.

PT. Vasa Sarwahita. (2016). Laporan Akhir Rencana Pencegahan dan Peningkatan Kualitas Permukiman Kumuh Perkotaan (RP2KPKP) Kabupaten Pekalongan. 